\title{
Article \\ Performance Evaluation of Particulate Matter and Indoor Microclimate Monitors in University Classrooms under COVID-19 Restrictions
}

\author{
Laurentiu Predescu ${ }^{1}$ and Daniel Dunea ${ }^{2, *(D)}$ \\ 1 Department of Food Engineering, Faculty of Environmental Engineering and Food Science, Valahia \\ University of Targoviste, Aleea Sinaia No. 13, 130004 Targoviste, Romania; laurentiu.predescu@valahia.ro \\ 2 Department of Environmental Engineering, Faculty of Environmental Engineering and Food Science, \\ Valahia University of Targoviste, Aleea Sinaia No. 13, 130004 Targoviste, Romania \\ * Correspondence: dan.dunea@valahia.ro; Tel.: +40-769-076-854
}

check for updates

Citation: Predescu, L.; Dunea, D. Performance Evaluation of Particulate Matter and Indoor Microclimate Monitors in University Classrooms under COVID-19 Restrictions. Int. J. Environ. Res. Public Health 2021, 18, 7363. https:// doi.org/10.3390/ijerph18147363

Academic Editors: Tareq Hussein and Francesca Costabile

Received: 11 June 2021

Accepted: 7 July 2021

Published: 9 July 2021

Publisher's Note: MDPI stays neutral with regard to jurisdictional claims in published maps and institutional affiliations.

Copyright: (c) 2021 by the authors. Licensee MDPI, Basel, Switzerland. This article is an open access article distributed under the terms and conditions of the Creative Commons Attribution (CC BY) license (https:/ / creativecommons.org/licenses/by/ $4.0 /)$.

\begin{abstract}
Optical monitors have proven their versatility into the studies of air quality in the workplace and indoor environments. The current study aimed to perform a screening of the indoor environment regarding the presence of various fractions of particulate matter (PM) and the specific thermal microclimate in a classroom occupied with students in March 2019 (before COVID-19 pandemic) and in March 2021 (during pandemic) at Valahia University Campus, Targoviste, Romania. The objectives were to assess the potential exposure of students and academic personnel to PM and to observe the performances of various sensors and monitors (particle counter, PM monitors, and indoor microclimate sensors). PM1 ranged between 29 and $41 \mu \mathrm{g} \mathrm{m}^{-3}$ and PM10 ranged between 30 and $42 \mu \mathrm{g} \mathrm{m}^{-3}$. It was observed that the particles belonged mostly to fine and submicrometric fractions in acceptable thermal environments according to the PPD and PMV indices. The particle counter recorded preponderantly $0.3,0.5$, and 1.0 micron categories. The average acute dose rate was estimated as $6.58 \times 10^{-4} \mathrm{mg} / \mathrm{kg}$-day $(\mathrm{CV}=14.3 \%)$ for the $20-40$ years range. Wearing masks may influence the indoor microclimate and PM levels but additional experiments should be performed at a finer scale.
\end{abstract}

Keywords: PM2.5; PM1; size segregated mass fractions; thermal microclimate; predicted mean vote (PMV); predicted percentage of dissatisfied (PPD); particle counter; mask wearing; acute dose rate (ADR)

\section{Introduction}

Particulate matter (PM) represents small particles that range in size from less than 1 micron to about 100 microns [1]. These particles remain suspended in the environment for a long time. When they are inhaled in various microenvironments, they penetrate deep into the lungs, having the direct effect of increasing morbidity in the exposed individuals [2]. These particles are also responsible for significant economic losses due to their corrosive properties and adhesion to the surfaces on which they eventually settle down [3].

A particle diameter of fewer than 10 microns was considered to protect human health because it can enter the thoracic cavity through respiration. Inhalable particles larger than 10 microns in diameter have a much lower potential effect on health. In the United States, this standard entered into force on 31 July 1987 [4]. Under the Air Quality Directive 2008/EC/50, the European Union has set limit values for outdoor particulate matter (PM10 and PM2.5) regarding the protection of human health, (https:/ / eur-lex.europa.eu/eli/dir/ 2008/50/oj, accessed on 5 June 2021).

The main adverse effects on the health of the population are generated by particles with an aerodynamic diameter of fewer than 10 micrometers, which pass through the nose and throat, reaching the lung alveoli causing inflammation and intoxication [5]. The 
most affected vulnerable groups are people with cardiovascular and respiratory diseases, children, the elders, and asthmatics [6]. Long-term exposure to a constant concentration of suspended particles can cause cancer and premature death $[7,8]$.

Young people inhale a higher amount of air, and depending on its load, it results in a more pronounced exposure to the concentrations of air pollutants [9]. It has been demonstrated that PM aggravates the symptoms of asthma, manifested by breathing difficulties, cough, chest pain, etc. [10]. More attention should be given for the fractions lower than $4 \mu \mathrm{m}$ considered as a threshold for the respirable fraction [11].

PM is a potential carrier of allergens or microorganisms, including viruses, which are unable to survive separately. Studies have found that PM1 and PM2.5 are viruscarrying particles that can be inhaled into the lower respiratory tract triggering an immune response and increasing secretions and expressions of inflammatory cytokines [12]. Recent epidemiological studies pointed out that the smaller the particle diameter, the higher the possibility of deeper penetration into the lungs up to the alveolar level $[13,14]$. A study in Belgium involving measurements of a large number of indoor and outdoor air pollutants at 30 elementary schools ( 90 classrooms total) demonstrated that concentrations of many chemicals including various fractions of PM were much higher indoors than outdoors. It also showed high variability in concentrations between classrooms [15]. A recent study found that human walking induced indoor PM2.5 resuspension leads to an increase in indoor particulate matter requiring regular cleaning of the indoor dust to reduce the secondary pollution caused by indoor activities [16]. Within the university indoor environments, the main source of a PM is related to the resuspension of particles because of mobility of occupants and the outdoor concentrations enter indoors and remain inside the closed environment [17]. In these microenvironments, the students and academic personnel spend several hours being exposed to the concentrations of various air pollutants including PM. Thus, it is important to know the levels of exposure by using reliable sensors, methodology, and modeling algorithms [18].

The reference methods for measuring the mass concentration of suspended particulate matter (e.g., EN 12341:2014) are not capable of producing real-time data. EU regulations allow the use of equivalent methods if the equivalence of methods complies with the standards. It establishes a procedure for quantifying the correspondence between reference methods and equivalent methods through a series of parallel field measurements (CEN EN 16450:2017) [19].

The aim is for equivalent instruments to provide daily data with a lower measurement uncertainty than required by the ambient air quality directive ( $\pm 25 \%$ with a $95 \%$ confidence level) at concentrations close to the limit value. Gravimetric samplers with filters are mainly based on operators for their maintenance and operation, especially if the filters are changed daily and the subsequent weighing of the filters is necessary. Quality assurance of measurements must be strictly applied, due to the additional ways in which errors occur (e.g., handling of samples, transport, storage, and weighing). In addition, there may be delays (sometimes several days) between the sampling stage and the reporting stage for the filters to be weighed in a laboratory with special air conditioning conditions. This is detrimental to the updating of information for the protection of public health and is contrary to the reporting requirements of the directives in force [20]. Furthermore, the utilization of gravimetric samplers in indoor studies is difficult because of the information is required during the occupation of the analyzed room, which assumes various time intervals.

To overcome these shortcomings of the reference method, numerous PM10 and PM2.5 particle-measuring instruments (TEOM analyzer, beta attenuation monitor, optical devices, etc.) and later on, a series of low cost sensors have been developed [21]. Some of the existent equipment can also be used to measure the submicrometric fraction by changing the impactor or cyclone (particle pre-selection devices according to the particle diameter) or use a cascade impactor for several fractions [22].

Particle analyzers using optical methods are based on estimating the interaction between suspended particles, on the one hand, and visible or infrared spectrum radiation 
or a laser beam, on the other. Nephelometric systems that operate based on a short closed path to propagate the emitted radiation measure the light scattering responsible for most of the total amount of light extinction. The advantage of these instruments is that a single device can simultaneously monitor the fine particles-PM10 and PM2.5, but also the submicrometric ones (PM1) [23]. Among other applications in which optical monitors have proven their versatility are the studies of air quality in the workplace and indoor environments [24].

The aim of the study was to perform a screening of the indoor environment regarding the presence of various fractions of particulate matter (PM) and specific thermal microclimate in a classroom occupied with students in March 2019 (before COVID pandemic) and in March 2021 (during pandemic) at Valahia University Campus, Targoviste, Romania. The research hypothesis presumed differences between the groups of students on PM load and indoor microclimate in the university classroom due to the number of occupants and the use of masks. The objectives were to further assess the potential exposure of students and academic personnel to PM and to observe the performances of various sensors and monitors (particle counter, PM monitors, and indoor microclimate sensors). The results are expected to provide contextual data for environmental exposure assessment and useful insights about the influence of wearing masks on the indoor microclimate modifications, and give perspectives for the future of sensors that can support medical and occupational health and safety research in indoor environments. Furthermore, the study provides several insights regarding the impact of COVID-19 safety regulations on indoor air quality in a university classroom considering human patterns in view of developing proper mitigation strategies.

\section{Materials and Methods}

The experiments were performed at different times in the same classroom located at the 2nd floor of a fourth story building from the campus, which was finalized in 2015 with a modern building envelope respecting the standards. It is watertight and wind speed or temperature differences have less impact on the indoor measurements. The orientation of the classroom is south-east as seen on the topographic map (Figure S1). The classroom is equipped with a whiteboard with non-permanent markers, copy machine, video-projector, and three desktop computers that may contribute to the emissions and resuspension of PM (Figure S2). The dimensions of the classroom are typical for the campus in agreement with the regulations contained in the Romanian Civil Code. Consequently, the results can provide a general overview of the indoor conditions and a starting point for more detailed setups for assessing the health risks of students exposed to PM and other compounds. This will hopefully allow a better understanding of the factors and impacts related to indoor pollution during the educational process.

\subsection{Monitoring Instrumentation}

The PM measurements have been performed using a calibrated optical monitoring system and a particle counter. The TSI DustTrak ${ }^{\mathrm{TM}}$ DRX 8533 EP monitor is an optical instrument that simultaneously measures in real-time the size segregated mass fraction concentrations i.e., PM1, PM2.5, PM4, PM10, and TPM over $0.001-150 \mathrm{mg} / \mathrm{m}^{3}$ as concentration range [25]. Particle count in the $0.3-20 \mu \mathrm{m}$ range was achieved using an optical Lighthouse 3016 IAQ particle counter [26]. An HD32.3 portable datalogger from Delta OHM equipped with specific sensors for indoor microclimate analysis [27] was deployed in a corner opposite to the windows and accessing door in the same position as the PM monitors (Figure A1).

Thermal microclimate was assessed by the following indices: WBGT Index, PMV Index (Predicted Mean Vote), and PPD (Predicted Percentage of Dissatisfied) provided in the DeltaLog 10 application (Figures A2 and A3). The Scharlau Index was computed to estimate the thermal discomfort. 
The monitoring of outdoor concentrations was performed continuously using optical monitors located at the campus of the university (Figure S3). Concomitantly, outdoor temperature, relative humidity, and wind characteristics were recorded using a Delta-T Devices weather station (Figures S4 and S5). Figure S6 shows the time series of the recorded outdoor concentrations of PM2.5 and PM1 from which data were retrieved to compute average concentrations for the corresponding periods when the indoor measurements have been performed.

Furthermore, the reference indoor concentration of PM2.5 in the classroom without students and with windows and door closed was established for $3 \mathrm{~h}$ at approximately $11 \mu \mathrm{g} \mathrm{m}^{-3}$ - coeff. of var. $=11.2 \%$ (e.g., Figure S7).

\subsection{Physiological Characteristics of the Students and Classroom Description}

The interpretation of data required recording the classroom occupation (number of students, age and gender distribution, and physical activity levels of the occupants) during measurements (Table 1). In addition, all actions on ventilation and heating were recorded. Functional probes were retrieved using a questionnaire completed by each student with his consent to participate in the study.

Indirect estimation of the physiological probes of students has been considered based on the respiratory characteristics such as minute ventilation (VE) and alveolar minute ventilation (AVE). Minute ventilation is the amount of air breathed per minute equaling approximately $6 \mathrm{~L}$ (normal rate of minute ventilation is 5 to $8 \mathrm{~L} / \mathrm{min}$ ). For example, tidal volumes of 500 to $600 \mathrm{~mL}$ at 12-14 breaths/min provide VE between 6.0 and $8.4 \mathrm{~L}$. VE can double with light exercise, and it can exceed $40 \mathrm{~L} / \mathrm{min}$ with heavy exercise. Around $2 \mathrm{~L}$ remain in the physiological dead space (VD) consisting of the upper airway and the mouth, and $4 \mathrm{~L}$ participate in gas exchange in the millions of alveoli constituting the alveolar ventilation [28]. Two respiratory rates have been taken into account considering a sedentary activity i.e., $f_{1}=10-11$ breathes/min without a mask in 2019 and $f_{2}=12-14$ breathes/min for the groups wearing a mask in 2021. Equations and used values are presented in Table 1.

It was considered that air movement at the level of the classroom's occupants must be at a temperature and velocity to ensure proper comfort. Likewise, the natural ventilation should be controllable to allow users to adjust the ventilation rate as required. Adjustments were achieved by the appropriate use of windows and a door. The classroom has a volume of $150 \mathrm{~m}^{3}$ and only natural ventilation was used by opening the windows at every $60 \mathrm{~min}$ for $5 \mathrm{~min}$ in the interval of three hours of practical works. The volume per person and the nominal occupancy are presented in Table 1.

Table 1. Setup of the experiment to determine the PM load and thermal microclimate in a university classroom in the presence of various groups of students without masks (2019) and with disposable face masks (2021).

\begin{tabular}{ll}
\hline Indicator & Descriptor \\
\hline Location & Valahia University Campus, Targoviste, Romania-Classroom A227 \\
\hline Study period & 3 h monitoring for each group in different days of March 2019 and in March \\
& 2021 (with anti-COVID protection measures) \\
\hline Groups of & 2019-2 groups \\
students & A $(n=17)$-age (18-38); 13 females and 4 males. \\
& B $(n=17)$-age (19-38); 14 females and 3 males. \\
& 2021-2 groups \\
& C $(n=9)$-age (19-30); 9 females. \\
& D $(n=9)$-age (19-43); 7 females and 2 males. \\
& Total $=52$ students +1 professor which was present in all groups (male) \\
\hline
\end{tabular}


Table 1. Cont.

\begin{tabular}{|c|c|}
\hline Indicator & Descriptor \\
\hline $\begin{array}{l}\text { Fields in the } \\
\text { observation } \\
\text { sheet completed } \\
\text { by each student }\end{array}$ & $\begin{array}{l}\text { age; weight; height; medication during the trial; presence of respiratory } \\
\text { symptoms; physical effort before entering in the classroom; body temperature } \\
\text { before entering the classroom. }\end{array}$ \\
\hline Classroom & $\begin{array}{l}\text { Surface }\left(\mathrm{m}^{2}\right)=50 ; \text { Height }(\mathrm{m})=3 \text {; Volume }\left(\mathrm{m}^{3}\right)=150 \text {; } \\
\text { Volume per person }\left(\mathrm{m}^{3} / \text { person) }\right. \\
\text { A-8.33 } \\
\text { B-8.33 } \\
\text { C-15 } \\
\text { D-15 } \\
\text { Nominal occupancy }\left(\text { person } / \mathrm{m}^{2}\right) \\
\text { A-0.36 } \\
\text { B- } 0.36 \\
\text { C-0.2 } \\
\text { D- } 0.2\end{array}$ \\
\hline $\begin{array}{l}\text { Respiratory } \\
\text { characteristics }\end{array}$ & 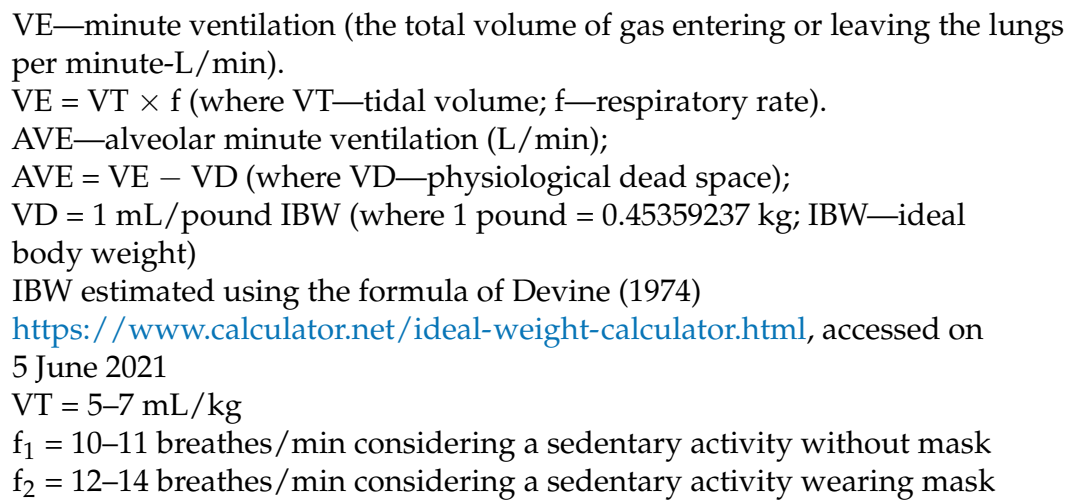 \\
\hline
\end{tabular}

\subsection{Analysis, Modeling, and Statistics}

To obtain insights into the exchange rate of the air and other exogenous parameters that are influencing the indoor levels of PM2.5, a mass balance equation was considered using the parameters provided in [29], which monitored outdoor average concentrations of PM2.5 during indoor measurements and no filtration conditions:

$$
C_{i}=C_{o} \frac{P \cdot \lambda_{V}}{\lambda_{V}+\lambda_{D}+\lambda_{F}}+\frac{E}{\left(\lambda_{V}+\lambda_{D}+\lambda_{F}\right) V}
$$

where:

$C_{i}$ - concentration of $\mathrm{PM}_{2.5}\left(\mu \mathrm{g} \mathrm{m}^{-3}\right)$;

$\mathrm{C}_{0}$-ambient air concentration of $\mathrm{PM}_{2.5}\left(\mu \mathrm{g} \mathrm{m}^{-3}\right)$ (according to the recorded average for each group: $69,40,25$, and $32 \mu \mathrm{g} \mathrm{m}^{-3}$ );

$P$-penetration factor (unitless) $=0.97$;

$\lambda_{V}$-infiltration ventilation rate $\left(\mathrm{h}^{-1}\right)=0.53$;

$\lambda_{D}$-particle removal rate by deposition $\left(\mathrm{h}^{-1}\right)=0.39$;

$\lambda_{F}$-particle removal rate by filtration $\left(\mathrm{h}^{-1}\right)=0$-no filtration;

$E-\mathrm{PM}_{2.5}$ total emissions from indoor sources $\left(\mu \mathrm{g} \mathrm{h}^{-1}\right)=2.62$;

$V$-room volume $\left(\mathrm{m}^{3}\right)=150$.

Variations of this model were successfully used to assess the potential inhaled dose rate of particles [30] including SARS-CoV-2 virus [31], and the parametric analysis to examine indoor PM2.5 concentrations according to flow rates and filter efficiency under various outdoor concentrations and indoor levels [32]. 
In the current work, ExpoFIRST version 2.0, which is a standalone tool available for download from the Exposure Factors module of the EPA-Expo-Box website (https: / / cfpub.epa.gov / ncea/risk/recordisplay.cfm?deid=322489, accessed on 5 June 2021), was considered for performing an exposure assessment by entering data in five tabs to estimate inhalation ADD (Figure A4). In Scenario Description tab, the route of exposure, dose metric, and exposure descriptor were described, and then, in tab 2: Media \& Receptors, the inhalation rate type (e.g., long-term (daily), short-term (activity-specific); intensity level when short-term is selected), location/activity, and receptor characteristics (gender and age bins), respectively. The next tabs are tab 3: Contaminants for entering chemical-specific information, and tab 4: Exposure Factors that lists each receptor group based on age.

Descriptive statistics (average, coefficient of variation, skewness, and kurtosis) provided the main features of the dataset variability. Normal distribution was tested based on Sig. value results from two tests of normality (Kolmogorov-Smirnov and Shapiro-Wilk tests). A non-parametric Mann-Whitney U test was used to compare the differences between two independent groups of unequal size [33] to test whether two samples (without disposable masks and with masks) are likely to derive from the same population $\left(\mathrm{H}_{0}\right.$ : the populations are equal versus $\mathrm{H}_{1}$ : the populations are not equal). The test ranks all of the dependent values and then uses the sum of the ranks for each group in the calculation of the test statistic. Linear trendlines of PM time series were compared based on $\mathrm{R}^{2}$.

\section{Results}

The main results of this screening study were the characterization of PM load in the classroom together with the thermal comfort and the estimation of the ventilation parameters of the participating groups of students. These indicators will establish the framework for a modeling approach for simulating the exposure of students and academic personnel in the University's classrooms.

\subsection{Particulate Matter Load}

The measurements performed in the classroom provided an overview of the PM load in the presence of various groups of students. Table 2 presents the statistics of the PM concentrations for various size fractions. PM1 ranged between 29 and $41 \mu \mathrm{g} \mathrm{m}^{-3}$ and PM10 between 30 and $42 \mu \mathrm{g} \mathrm{m}^{-3}$. It was observed that the particles belonged mostly to fine and submicrometric fractions, reaching a maximum value of $51 \mu \mathrm{g} \mathrm{m}^{-3}$ in Group D. While analyzing the corresponding time series, a decrease of the PM concentration towards the end of the lectures occurred both in A and B groups. PM levels remained constant in Group C and D in which students wore disposable face masks (Figure 1).

The $\mathrm{R}^{2}$ of linear trendlines confirmed the decrease in $\mathrm{A}\left(\mathrm{R}^{2}=0.86\right)$ and $\mathrm{B}\left(\mathrm{R}^{2}=0.69\right)$ groups and the constancy in $C\left(R^{2}=0.00\right)$ and $D\left(R^{2}=0.06\right)$ groups. Table 3 shows the data collected by the particle counter, which correlates with the results regarding the mass concentrations provided by the PM optical monitor. Most of the particles corresponded to the $0.3,0.5$, and 1.0 micron classes. Groups $C$ and D recorded preponderantly 0.3 micron particles $(7,006,334$ and 5,097,065), while A and B in 0.5 microns category $(6,183,560$ and $6,013,148)$, respectively.

The mass balance approach provided approximations of the PM2.5 indoor concentration based on outdoor levels and other factors. Table 4 presents a comparison between modeled concentrations and the averaged values resulting from monitoring. While for Group A there is an agreement between both values and partially for Group B, the concentrations recorded during pandemics showed higher indoor concentrations suggesting that probably the rate of emissions from indoor sources could be higher. One potential cause could be the use of disinfectants and hand sanitizers, but this assumption must be checked through detailed experiments involving chemical speciation determination. 
Table 2. Concentration of the size segregated mass fractions of particulate matter $\left(\mu \mathrm{g} \mathrm{m}^{-3}\right)$ recorded in a classroom using a TSI DustTrak ${ }^{\mathrm{TM}}$ DRX $8533 \mathrm{EP}$ monitor during $3 \mathrm{~h}$ of lecture in the presence of students (Group A and B-without wearing masks; Group C and D-wearing disposal face masks).

\begin{tabular}{ccccc}
\hline PM & Group A & Group B & Group C & Group D \\
\hline PM1 Average & 36 & 30 & 29 & 41 \\
PM1 Minimum & 32 & 27 & 24 & 31 \\
PM1 Maximum & 45 & 33 & 34 & 51 \\
Coeff. of var. & 9.0 & 6.0 & 10.3 & 10.9 \\
PM2.5 Average & 37 & 30 & 29 & 41 \\
PM2.5 Minimum & 33 & 27 & 24 & 32 \\
PM2.5 Maximum & 45 & 33 & 34 & 52 \\
Coeff. of var. & 9.1 & 6.0 & 10.1 & 11.0 \\
PM4 Average & 37 & 31 & 30 & 41 \\
PM4 Minimum & 33 & 28 & 24 & 32 \\
PM4 Maximum & 45 & 34 & 35 & 52 \\
Coeff. of var. & 8.9 & 5.8 & 10.0 & 11.0 \\
PM10 Average & 38 & 31 & 30 & 42 \\
PM10 Minimum & 33 & 28 & 25 & 32 \\
PM10 Maximum & 46 & 35 & 36 & 53 \\
Coeff. of var. & 9.1 & 5.9 & 9.6 & 10.8 \\
\hline
\end{tabular}

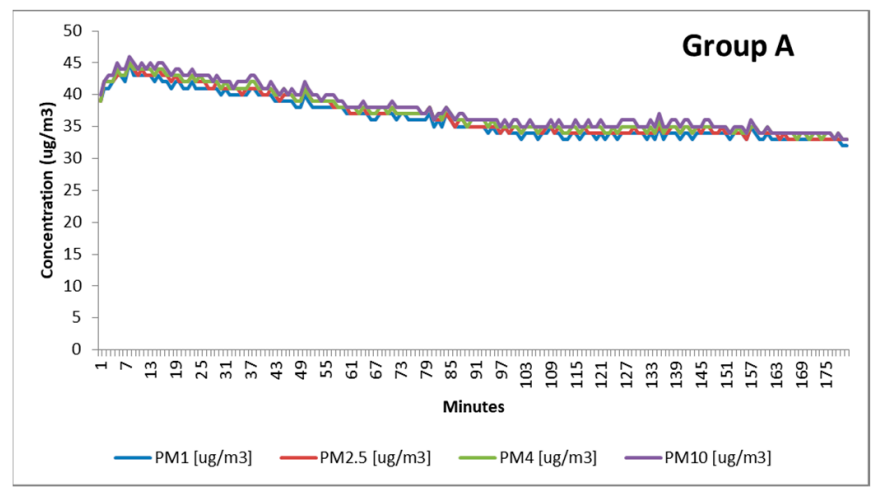

(a)

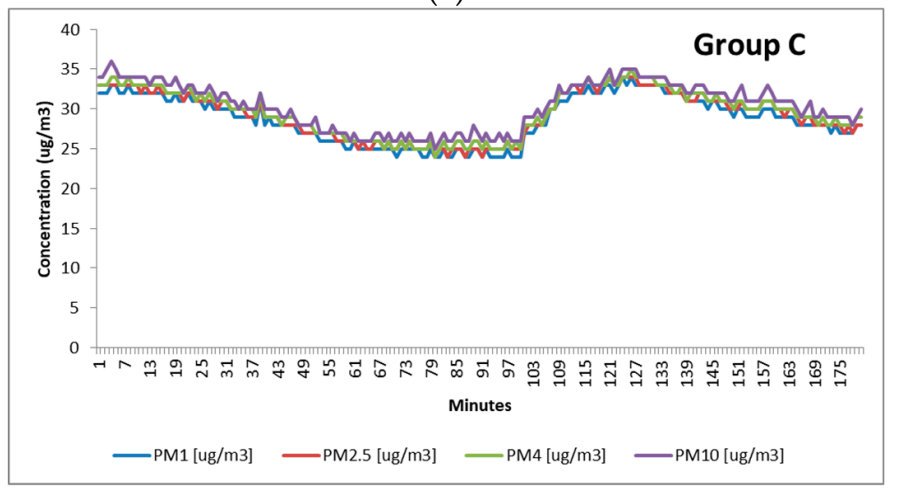

(c)

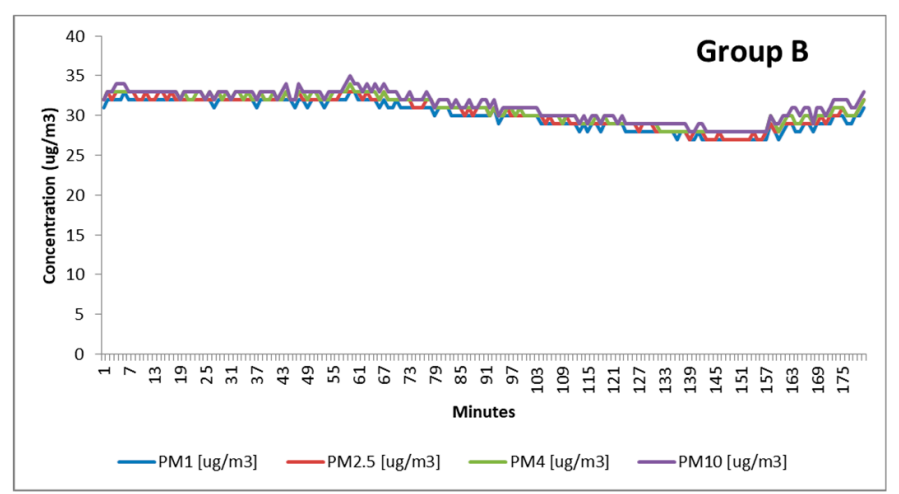

(b)

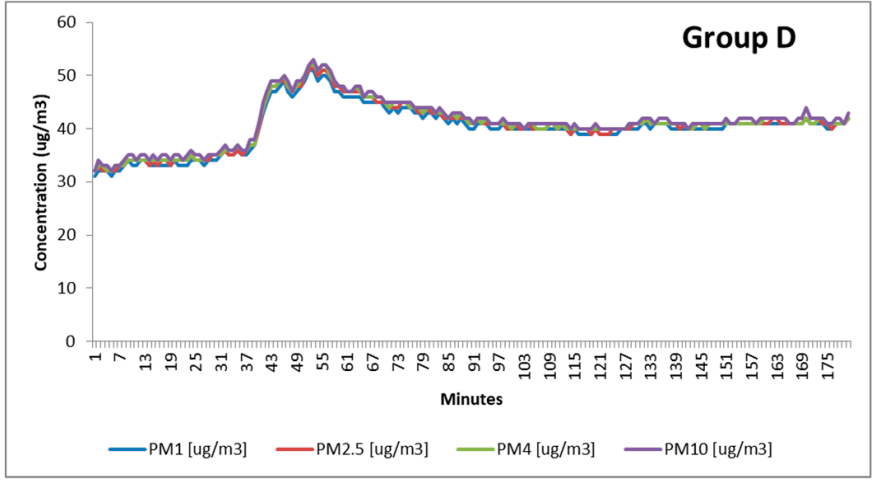

(d)

Figure 1. Time series of the concentrations of the size segregated mass fractions of particulate matter $\left(\mu \mathrm{g} \mathrm{m}^{-3}\right)$ recorded in a classroom using a TSI DustTrak ${ }^{\mathrm{TM}}$ DRX 8533 EP during three hours of lectures and the equations of corresponding linear trendlines: (a) Group A: $y=-0.0618 x+43.436\left(R^{2}=0.86\right)$; (b) Group B: $y=-0.0288 x+33.429\left(R^{2}=0.69\right)$; (c) Group C: $y=$ $-0.0002 x+30.3994\left(R^{2}=0.00\right) ;(d)$ Group D: $y=0.0214 x+39.407\left(R^{2}=0.06\right)$. 
Table 3. Particle counts and indoor microclimate recorded using the Lighthouse HH 3016 IAQ.

\begin{tabular}{cccccc}
\hline Size Fraction & Units & Group A & Group B & Group C & Group D \\
\hline 0.3 micron & (Counts) & $3,453,673$ & $3,584,492$ & $7,006,334$ & $5,097,065$ \\
0.5 micron & (Counts) & $6,183,560$ & $6,013,148$ & 676,944 & $4,368,051$ \\
1.0 micron & (Counts) & 349,388 & 371,017 & 240,909 & 416,673 \\
2.5 micron & (Counts) & 10,564 & 23,055 & 88,378 & 75,916 \\
5.0 micron & (Counts) & 2409 & 7736 & 30,054 & 38,044 \\
10.0 micron & $($ Counts) & 405 & 551 & 1280 & 4250 \\
Sample Time & $(\mathrm{s})$ & 10,800 & 10,800 & 10,800 & 10,800 \\
Sample Volume & $\left(\mathrm{m}^{3}\right)$ & 0.510 & 0.510 & 0.510 & 0.510 \\
Temperature & $\left({ }^{\circ} \mathrm{C}\right)$ & 26.0 & 25.7 & 22.4 & 24.2 \\
Relative Humidity & $(\%)$ & 25.2 & 24.4 & 42.4 & 20.4 \\
\hline
\end{tabular}

Table 4. Results of the mass balance approach to estimate the indoor concentrations of PM2.5 $\left(\mu \mathrm{g} \mathrm{m}^{-3}\right)$.

\begin{tabular}{cccccc}
\hline Group & $\begin{array}{c}\text { Monitored PM2.5 } \\
\text { Outdoor Range }\end{array}$ & $\begin{array}{c}\text { Average Outdoor } \\
\text { PM2.5 Concentration } \\
\left(\mathbf{C}_{\mathbf{0}}\right)\end{array}$ & $\begin{array}{c}\text { Indoor Modeled } \\
\text { Concentration (C) }\end{array}$ & $\begin{array}{c}\text { Indoor Measured } \\
\text { Concentration }\end{array}$ & $\begin{array}{c}\text { Required Outdoor } \\
\text { Concentration to Reach } \\
\text { Indoor Values }\end{array}$ \\
\hline A & $62-71$ & 69 & 38.5 & 37 & 66 \\
B & $31-47$ & 40 & 22.2 & 30 & 54 \\
C & $22-28$ & 25 & 14.2 & 29 & 52 \\
D & $26-34$ & 32 & 17.9 & 41 & 73 \\
\hline
\end{tabular}

\subsection{Thermal Comfort}

The thermal comfort was estimated using a series of indices from which the most precise one reflects the influence of the physical and physiological variables on the thermal comfort i.e., PMV and PPD in relation to precise microclimatic conditions. Figure 2 shows the monitoring of various temperature types required for the computation of thermal comfort indices.

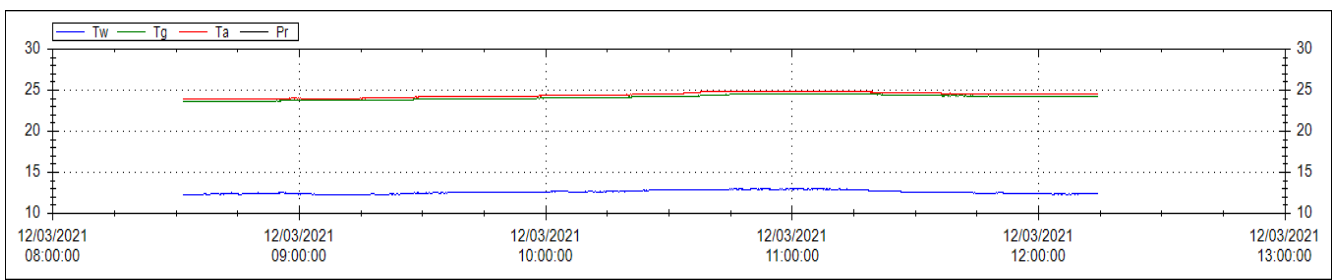

Figure 2. Example of the raw time series recorded by the DeltaOHM indoor microclimate system during the practical works of Group D (Tw—wet bulb temperature with natural ventilation; $\mathrm{Tg}$ globe thermometer temperature; $\mathrm{Ta}$-ambient temperature; $\mathrm{Pr}$-vapor pressure).

Table 5 summarizes the results for each group showing a better thermal environment for groups $C$ and D compared to the other two groups. PMV varied between 0.4 and 0.8 , while PPD was between $9.2 \%$ and $16.4 \%$. The A and B groups were characterized by acceptable thermal environment, while $C$ and $D$ reached the thermal well-being status.

Table 5. Thermal indicators estimated using the DeltaOHM HD32.3 during the practical works of students $(3 \mathrm{~h})$.

\begin{tabular}{ccccc}
\hline Indicator & Group A & Group B & Group C & Group D \\
\hline PMV & 0.8 & 0.7 & 0.5 & 0.4 \\
PPD (\%) & 16.4 & 15.7 & 11.1 & 9.2 \\
WBGT & 22.4 & 20.3 & 16.5 & 16.1 \\
Scharlau Index & $13.9^{\circ} \mathrm{C}$ & $15.8^{\circ} \mathrm{C}$ & $6.5^{\circ} \mathrm{C}$ & $19.5^{\circ} \mathrm{C}$ \\
Critical temperature & $39.9^{\circ} \mathrm{C}$ & $41.8^{\circ} \mathrm{C}$ & $30.9^{\circ} \mathrm{C}$ & $43.7^{\circ} \mathrm{C}$ \\
\hline
\end{tabular}

Thermal environment evaluation: PMV $=+0.85$; PPD $=20 \%$-acceptable thermal environment; $-0.5<$ PMV < +0.5 and PPD $<10 \%$-thermal well-being. 


\subsection{Variability of Respiratory Characteristics between the Groups of Students}

The results regarding the respiratory characteristics were retrieved indirectly based on the estimations using functional probes declared by the students. Table 6 shows the main statistics including the minute ventilation (VE) and alveolar minute ventilation (AVE) for each group. During three hours in the closed environment of the classroom, the alveolar minute ventilation of the groups including the participating students and the same lecturer were as follows Group A 11,884.3 L, Group B 11,123.9 L, Group C 8138.88 L, and Group D $8382.93 \mathrm{~L}$. The latest two groups had higher ventilation rates due to the mask wearing. The means of alveolar minute ventilation rates ranged between 3.3 and $4.5 \mathrm{~L} / \mathrm{min}$ with coefficients of variations between $13.3 \%$ and $24.5 \%$ depending on the structure of the group (age, sex, height, and weight). Mann-Whitney U tests showed significant differences $(p<0.05)$ between Group A and Group C ( $\mathrm{U}$-value $=34.5$; $\mathrm{U}$ critical value of at $p<0.05=39$; $p=0.025)$, respectively Group A and Group D (U-value $=36$; $\mathrm{U}$ critical value of at $p<0.05$ $=39 ; p=0.030)$. The differences between $\mathrm{B}$ and $\mathrm{C}(\mathrm{U}$-value $=21 ; \mathrm{U}$ critical value at $p<0.01$ $=29 ; p=0.003)$, and $\mathrm{B}$ and $\mathrm{D}(\mathrm{U}$-value $=12 ; \mathrm{U}$ critical value at $p<0.01=29 ; p=0.0005)$ groups had significant results at $p<0.01$.

Table 6. Variability of functional probes and respiratory characteristics between the groups of students.

\begin{tabular}{|c|c|c|c|c|c|c|c|c|c|c|}
\hline Students & Statistical Indicator & Age & Weight & Height & VT & VE & IBW & VD & AVE & Total AVE in $3 \mathrm{~h}$ \\
\hline Units & - & years & kg & $\mathbf{m}$ & $\mathrm{mL} / \mathrm{kg}$ & $\mathrm{L} / \mathrm{min}$ & kg & $\mathbf{L}$ & $\mathrm{L} / \mathrm{min}$ & $\mathrm{L} / \mathrm{min}$ \\
\hline \multirow{6}{*}{$\begin{array}{c}\text { Group A } \\
(n=17)\end{array}$} & Average & 24.1 & 59.8 & 1.7 & 351.1 & 3.5 & 60 & 0.1 & 3.4 & 645.7 \\
\hline & Min. & 18 & 35.4 & 1.5 & 212.4 & 2.1 & 41.5 & 0.1 & 2 & 382.3 \\
\hline & Max. & 38 & 92 & 1.8 & 552 & 5.5 & 76 & 0.2 & 5.4 & 993.6 \\
\hline & Coeff. of var. (\%) & 29 & 24 & 5 & 24.5 & 24.5 & 15.2 & 15.1 & 24.5 & 24 \\
\hline & Skewness & 1.3 & 0.6 & -0.6 & 0.6 & 0.6 & -0.3 & -0.3 & 0.7 & 0.6 \\
\hline & Kurtosis & 0.1 & 0.3 & 0.4 & 0.3 & 0.3 & -0.3 & -0.3 & 0.3 & 0.3 \\
\hline \multirow{6}{*}{$\begin{array}{c}\text { Group B } \\
(n=17)\end{array}$} & Average & 22.8 & 58 & 1.7 & 345.4 & 3.4 & 59.7 & 0.1 & 3.3 & 597.9 \\
\hline & Min. & 19 & 48 & 1.6 & 288 & 2.9 & 52.4 & 0.1 & 2.8 & 496.5 \\
\hline & Max. & 38 & 80 & 1.8 & 480 & 4.8 & 75.1 & 0.2 & 4.7 & 839.6 \\
\hline & Coeff. of var. (\%) & 23.8 & 14.4 & 4.0 & 14.5 & 14.5 & 12.0 & 12.0 & 14.9 & 14.9 \\
\hline & Skewness & 1.7 & 1.1 & 0.8 & 1.1 & 1.1 & 0.9 & 0.9 & 1.1 & 1.1 \\
\hline & Kurtosis & 2.7 & 1.5 & -0.5 & 1.5 & 1.5 & -0.2 & -0.2 & 1.7 & 1.7 \\
\hline \multirow{6}{*}{$\begin{array}{c}\text { Group C } \\
(n=9)\end{array}$} & Average & 21.6 & 60.4 & 1.63 & 362.7 & 4.3 & 54.8 & 0.1 & 4.2 & 783.3 \\
\hline & Min. & 19 & 49 & 1.5 & 294 & 3.5 & 45.1 & 0.1 & 3.4 & 635 \\
\hline & Max. & 30 & 70 & 1.7 & 420 & 5 & 59.7 & 0.1 & 4.9 & 907.2 \\
\hline & Coeff. of var. (\%) & 19.8 & 13 & 2.9 & 13 & 13 & 7.8 & 7.8 & 13.3 & 13 \\
\hline & Skewness & 1.6 & -0.5 & -1.6 & -0.5 & -0.5 & -1.6 & -1.6 & -0.5 & -0.5 \\
\hline & Kurtosis & 1.0 & -1.4 & 3.2 & -1.4 & -1.4 & 3.2 & 3.2 & -1.4 & -1.4 \\
\hline \multirow{6}{*}{$\begin{array}{l}\text { Group D } \\
(n=9)\end{array}$} & Average & 24.8 & 64.7 & 1.7 & 388 & 4.7 & 62.5 & 0.1 & 4.5 & 813.3 \\
\hline & Min. & 19 & 45 & 1.6 & 270 & 3.2 & 52.4 & 0.1 & 3.1 & 562.4 \\
\hline & Max. & 43 & 80 & 1.9 & 480 & 5.8 & 75.2 & 0.2 & 5.6 & 1012.4 \\
\hline & Coeff. of var. (\%) & 40.6 & 21.7 & 5.1 & 21.7 & 21.7 & 12.8 & 12.8 & 22.1 & 22.1 \\
\hline & Skewness & 1.6 & -0.1 & 0.2 & -0.1 & -0.1 & 0.2 & 0.2 & -0.1 & -0.1 \\
\hline & Kurtosis & 0.7 & -2.0 & -1.0 & -2.0 & -2.0 & -1.0 & -1.0 & -2.0 & -2.0 \\
\hline
\end{tabular}

The central tendency parameters such as age, body weight, and inhalation rates were used as inputs in the ExpoFIRST tool to assess ADR values for each group of students. Figure 3 shows the results for the age range and various age bins (20-30 years and 3140 years). The average ADR for all groups was estimated as $6.58 \times 10^{-4} \mathrm{mg} / \mathrm{kg}$-day $(\mathrm{CV}=14.3 \%)$ for 20-40 years range, while for 20-30 years bin the average was $7.38 \times 10^{-4}$ $\mathrm{mg} / \mathrm{kg}$-day $(\mathrm{CV}=18.9 \%)$ and $5.74 \times 10^{-4} \mathrm{mg} / \mathrm{kg}$-day $(\mathrm{CV}=9.2 \%)$ for $31-40$ years bin, respectively. 


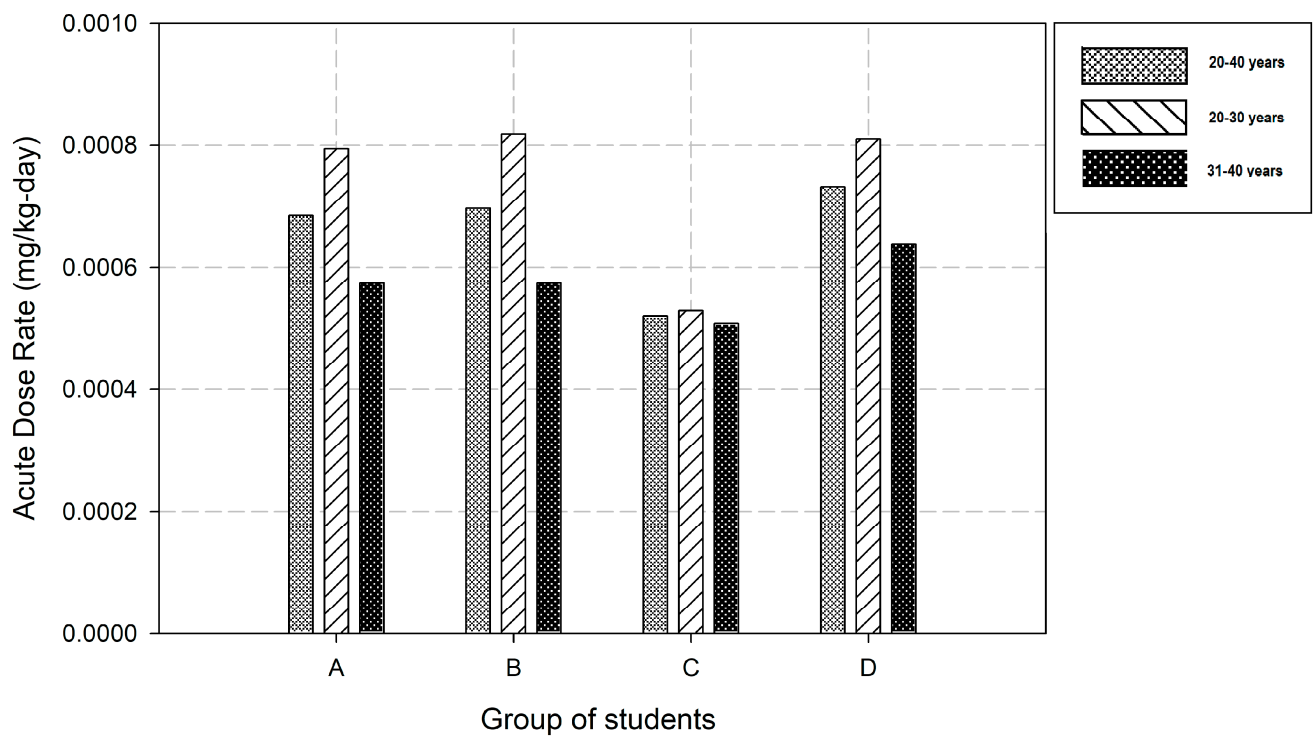

Figure 3. Acute dose rates estimated for the groups of students (A, B, D-mixed groups; C-only females); columns order: 20-40 years; 20-30 years; $31-40$ years.

\section{Discussion}

In a room, the assessment of air exchange rate requires longer-term measurements to determine the prevailing conditions influenced by several exogenous parameters. The pollutants' load in the air within a classroom has similarities with the outdoor air from surrounding sources coming in through infiltration and airing. An increase in ventilation rate facilitates the admission of outdoor pollutants and implicitly the removing and diluting effect of pollutants from indoor sources is counterbalanced by an increasing amount of pollutants originating from outdoor surroundings [34]. Indoor PM is considered to have preponderantly outdoor origins in schools [35]. In our study, the classroom is located in a building that is close to a major traffic road and some industrial sources [36]. However, due to the fact that the measurements were performed in a relatively colder period of time, the ventilation using windows was limited. Consequently, the density of human occupancy played an important role in the dynamics of indoor PM together with the inner sources. In the D group, which reached the highest PM concentration ( $\left.41 \mu \mathrm{g} \mathrm{m}^{-3} \mathrm{PM} 1\right)$, the increase of PM concentrations could be attributed to the use of hand sanitizers and disinfecting solutions used to fulfill the anti-COVID epidemiological regulations (Figure 1d). The concentrations recorded during the lectures of the other three groups (29-36 $\mu \mathrm{g} \mathrm{m}^{-3}$ PM1) may be considered as a benchmark for the classroom considered in this study regardless of the use of masks by the occupants. Other studies showed that the highest indoor PM10 levels were recorded in schools (33.0-97.2 $\mu \mathrm{g} \mathrm{m}^{-3}$ ) compared to homes (10.8-37.7 $\mu \mathrm{g} \mathrm{m}^{-3}$ ) and in schools, PM2.5 concentrations were considerably higher indoors $\left(9.4-56.1 \mu^{-3 ~ m^{-3}}\right)$ than outdoors $\left(8.6-15.8 \mu \mathrm{g} \mathrm{m}^{-3}\right)$ [37]. Our PM2.5 results $\left(37,30,29\right.$, and $41 \mu \mathrm{g} \mathrm{m}^{-3}$ corresponding for each group) are consistent with the concentrations reported in the literature by [38], such as: indoor levels measured in Paris between $24.7 \mu \mathrm{g} \mathrm{m}^{-3}$ in homes and $34.5 \mu \mathrm{g} \mathrm{m}^{-3}$ in offices versus $24.3 \mu \mathrm{g} \mathrm{m}^{-3}$ and $28.3 \mu \mathrm{g} \mathrm{m}^{-3}$, respectively, for adults and children in Amsterdam, $21.6 \mu \mathrm{g} \mathrm{m}^{-3}$ in Boston, $24 \mu \mathrm{g} \mathrm{m}^{-3}$ in Zurich, and 21.9 and $36.7 \mu \mathrm{g} \mathrm{m}^{-3}$ in Grenoble (for summer and winter, respectively). The reports regarding the submicrometric particles still needs to be further addressed and this study can contribute to the completion of the indoor air quality characterization. In the current study, particle counting data correlated with the results regarding the mass concentrations and most of the particles belonged to the $0.3,0.5$, and 1.0 micron classes. Because the normal activity in a classroom during the practical works is frontal lesson with students sitting at the desks, it is a sedentary activity only interrupted by intervals and lesson changes can cause resuspension of the particles [24]. Even a reduced activity can have a remarkable impact on 
airborne particles with diameters higher than $5 \mu \mathrm{m}$ [39]. Figure 1 shows that resuspension of these particles and coarse fraction were occurring more often in groups $A$ and C, while the lowest was in Group D. The importance of occupants' movement and of reduced ventilation in the indoor particulate level was underlined in [40]. On the other hand, indoor submicron particulate concentration can be rather correlated to the variability of the ventilation rate [24]. An increasing of air change per hour can involve an increment of indoor submicron particulate concentration especially in the moments when the external pollution reaches the top [34].

A decrease in the concentration of all the PM fractions was observed towards the end of the lectures, both in A and B groups with students that did not wear masks being before the COVID-19 pandemic. This could be attributed to the PM inhalation, filtering, and retaining capacity of respiratory mechanisms. PM concentration remained constant in groups $C$ and $D$ in which students wore disposable face masks. In [41], the protective effect of masks for everyday use made from different materials was tested against 20$1.000 \mathrm{~nm}$ particles with different velocities founding that $40-90 \%$ of aerosols were able to penetrate through these masks depending on the material and dampness. This might explain the massive presence of 0.3 micron particles during the lectures of groups $C$ and $D$ that wore masks. From a medical standpoint, there is a theoretical possibility of an airflow obstruction when wearing a mask [42]. Such effect should be further studied using proper instrumentation and protocols in conjunction with microclimate characterization [43]. Since the humans' thermal sensation is connected to the thermal energy balance of the whole human body, such balance is related to physical activity and clothing. In this study, the feeling of heat in the body as a whole was predicted by calculating PMV and PPD. PPD predicted the percentage of people who would feel too hot or too cold in the classroom environment. PPD varied being higher in larger groups $(n=18)$ i.e., $15.7 \%$ and $16.4 \%$ and lower in smaller ones $(n=10), 9.2 \%$ and $11.1 \%$, respectively. Thermal comfort can influence the ventilation rates [44]. In this study, we estimated the ventilation rates using well-established equations that use the functional probes of the classroom's occupants. Significant differences regarding the minute ventilation and alveolar minute ventilation were noticed between the groups that did not wear masks and the ones that did.

High levels of PM have been recorded in four different periods with different groups of students and the submicrometric fraction was the most present. The groups of students that did not wear masks (before COVID-19 pandemic) were exposed to PM and there exists the possibility that the decrease of the PM concentrations could be related to the inhaling and retaining of the PM in the students' lungs. The groups that wore masks have been better protected against PM and the PM remained constant during the $3 \mathrm{~h}$ of lecture taking into account the trendlines of the time series. In [45], the mean percent penetration of PM for each mask material ranged from $0.26 \%$ to $29 \%$, depending on the flow rate and mask material. It is clear that the mask efficiency in PM filtering should be considered to avoid empirical assessments.

The health effects of nanoparticles, which seem to be predominant in indoor environments, are better correlated to the surface area of the particles. More research should be performed involving personal monitoring of the respiratory functions of the participants by using spirometry and monitors that measure the dose of inhaled nanoparticles in the lungs (e.g., TSI NSAM 3550). Dynamic modeling should be also involved considering an indoor air mass balance with Monte Carlo simulations [29] involving also the complex effects of furniture/indoor thermal mass on building systems [46]. The goal is to achieve realistic models and aggregation methodologies for indoor mass elements [47].

On the other hand, another important issue in characterizing the indoor environments is the presence of mycotoxins that contributes to the 'Sick Building Syndrome' [48] caused by the biochemical manifestations of various micro-organisms [49].

There is a stringent need for low-cost portable tools for assessing the individual exposure to particulate matter (PM) and other air pollutants and mycotoxins of concerns in 
real-time [50]. The precision and reliability of the low-cost sensors for PM monitoring has increased in the last period having promising results [51,52].

Based on the study results, it is important to develop complex indoor surveys involving monitoring of air quality, thermal microclimate, and particularly the respiratory functions [53]. There are several useful insights that can be used in further experiments applying indoor air modeling [30,31], but more attention should be also given to mold and dampness, ventilation (determined from $\mathrm{CO}_{2}$ concentrations), and exposure to selected indoor air pollutants that are specific in the facilities of a university.

Indoor air modeling supports the understanding of viruses' inhalation transmission including SARS-CoV-2 in indoor environments by approximating how the inhaled amount of viruses is affected by factors such as room ventilation, breathing flow rate, gender, room size, aerosol size distribution, exposure time, level of exercise, and the type of vocal activity [31]. The lifelong sum of all the environmental contributions to human physiology and pathophysiology forms the exposome, which is a relatively new developed paradigm for studying the health consequences of the environment [32]. In addition to external environmental stressors, also lifestyle, socioeconomic status, and climate variations define the individual exposome [54]. In the current pandemic situation, there is also growing evidence that air pollution triggers comorbidities and increases the case fatality rate in patients with COVID-19 infection [55], whereas such epidemiological correlations are mostly missing for the characterization of various microenvironments including the indoor ones [56]. There is a need for developing multi-exposure concepts that include the most part of harmful environmental pollutants [54] besides PM.

Minimizing indoor air pollutants is important for a productive learning environment in universities because of the potentially negative effects determined by VOCs, PM including allergens and molds, and combustion gases on the health and wellbeing of students [57]. Some of these pollutants are known for causing flu-like symptoms, headaches, nausea, and irritation of the eyes, nose, and throat along with their capacity to trigger asthma or allergy attacks [57]. Air pollutants have been found to negatively influence academic performance [58]. Moreover, the combined effects of pollutants on the risk of COVID-19 infection and the severity of respiratory or cardiovascular complications are not well understood so far. On this basis, the current study aimed to characterize the indoor microenvironment for a typical classroom in which students and academic personnel spend a lot of time during the educational process (approximately $728 \mathrm{~h}$ /academic year-2 semesters), both for PM levels and microclimate in the presence of various groups of students. The resulted data can be used to establish efficient ways to diminish the exposure of students to PM providing better conditions for learning. Knowing that the exposure to environmental risk factors, which is the external exposome, leads to changes of central biochemical pathways (stress response, oxidative stress, and inflammation) with associated health impact, it is important to have reliable instrumentation for estimating the exposure to harmful pollutants. Since classical health risk factors share similar pathomechanisms, students' or professors' pre-existing chronic diseases (e.g., diabetes or hypertension) may experience additive adverse health effects upon exposure to environmental stressors especially in indoor microenvironments with high levels of air pollutants [54]. It is expected that precise monitoring will provide supporting data for a reliable epidemiological assessment and this study employed robust monitors for evaluating the exposure to PM. Additionally, the microclimate can contribute to the aggravation of health effects. Consequently, maintaining adequate air exchange rates do not replace or reduce the need to control indoor sources of emission of harmful chemicals [15]. Ventilation and filtration control play certainly a critical role in the variability of indoor PM2.5 concentrations of indoor or outdoor origin in different residential environments including educational facilities [59]. In the current work, the experiments relied on 'no filtration' conditions because the building in which the room is located still does not have a ventilation/filtration unit. However, it is previewed that such a unit will be added in the near future providing safer levels of PM during the learning process. 


\section{Conclusions}

The instrumentation used in this study showed promising results for the characterization of the indoor microenvironments including university buildings. PM load should be estimated together with the thermal microclimate, and the physiological indicators, clothes, and metabolic characteristics of the classroom's occupants. Such contextual data can provide useful insights on the indoor microclimate modifications, and give perspectives for the future of sensors that can support medical and occupational health and safety research in indoor environments.

We found that PM1 was the preponderant fraction ranging between 29 and $41 \mu \mathrm{g} \mathrm{m}^{-3}$ depending on the group of students in acceptable thermal environments according to the PPD and PMV indices. The particle counter recorded predominantly $0.3,0.5$, and 1.0 micron categories in the university classroom.

COVID-19 impacts on indoor air quality were determined especially by the use of various disinfectant products in the presence of a lower number of students due to the epidemiological restrictions. Outdoor monitoring showed a clear reduction of exterior PM concentrations during March 2021 compared to the same month in 2019 also due to the imposed measures for mobility restraints to control the spread of the virus.

The current approach has some limitations because individual testing of the students was not performed (spirometry, inhalation particularities, mask performance on filtering, and indoor microclimate influence) and some results have a broader context. Source apportionment, $\mathrm{CO}_{2}$ monitoring, and dynamic modeling should be also considered for a comprehensive characterization of the indoor exposure to PM. Due to epidemiological constraints, it was impossible to test the influence on mask wearing in the same group of students.

Future work will take into account more experimental setups considering the aspects mentioned before.

Supplementary Materials: The following are available online at https: / www.mdpi.com/article/ 10.3390/ijerph18147363/s1, Figure S1: Topographic map and image of Valahia University Campus showing the building in which the classroom is located at the 2nd floor (blue arrows), Figure S2: Interior of the classroom located at the 2nd floor where the experiments have been performed, Figure S3: Monitoring platform for particulate matter and meteorological parameters in Valahia University Campus (Casella Guardian 2, SELECT ONE Gravimetric Sampler, Rokidair microstation for PM measurements), Figure S4: Wind rose showing how wind speed and direction are typically distributed at the location $\left(\mathrm{m} \mathrm{s}^{-1}\right)$, Figure S5: Outdoor temperature $\left({ }^{\circ} \mathrm{C}\right)$ and relative humidity $(\%)$ in March 2019 and 2021, Figure S6: Outdoor concentrations of PM2.5 and PM1 $\left(\mathrm{g} \mathrm{m}^{-3}\right)$ recorded at 5 min rate in March 2019 and 2021, respectively, using the optical monitors located in the Valahia University Campus, Figure S7: Reference indoor concentration of particulate matter fractions in the classroom without students and with windows and door closed ( $3 \mathrm{~h}$ time series).

Author Contributions: D.D. developed the environmental monitoring setup, modeling, and interpretation of data and contributed to the writing of the manuscript. L.P. contributed to the experimental designs and writing of the manuscript providing experimental data helping with statistical processing of the recorded data sets. Both authors have read and agreed to the published version of the manuscript.

Funding: Data processing for publication and manuscript writing was funded by the Executive Unit for Financing Higher Education, Research, Development and Innovation (UEFISCDI) within [PN-III-P1-1.2-PCCDI-2017-0721—acronym INTER-ASPA].

Institutional Review Board Statement: Ethical review and approval were waived for this study, due to the complete data anonymization and privacy protection of the students participating in this study.

Informed Consent Statement: Informed consent was obtained from all subjects involved in the study.

Data Availability Statement: The data presented in this study are available on request from the corresponding authors. The data are not publicly available due to the potential for further development of the methodology. 
Acknowledgments: The authors want to thank the participating students, and the team of RokidAIR project (https: / / eeagrants.org/archive/2009-2014/ projects/RO14-0007, accessed on 5 June 2021) for their technical and administrative support in finalizing this study. The authors acknowledge the contribution of the editors and the two anonymous reviewers to the improvement of the original manuscript through useful comments and recommendations.

Conflicts of Interest: The authors declare no conflict of interest.

\section{Abbreviations}

IAQ indoor air quality

PM2.5 particles $<2.5 \mu \mathrm{m}$ in aerodynamic diameter;

PM4 particles $<4 \mu \mathrm{m}$ in aerodynamic diameter;

PM10 particles $<10 \mu \mathrm{m}$ in aerodynamic diameter;

$\mathrm{PN} \quad$ particle number $/ \mathrm{cm}^{3}$

TSP total suspended particles

VE minute ventilation $(\mathrm{L} / \mathrm{min})$.

VT tidal volume $(\mathrm{mL} / \mathrm{kg})$;

f respiratory rate.

AVE alveolar minute ventilation ( $\mathrm{L} / \mathrm{min})$;

VD physiological dead space (L);

IBW ideal body weight $(\mathrm{kg})$;

Tw wet bulb temperature with natural ventilation $\left({ }^{\circ} \mathrm{C}\right)$;

$\mathrm{Tg}$ globe thermometer temperature $\left({ }^{\circ} \mathrm{C}\right)$;

Ta ambient temperature $\left({ }^{\circ} \mathrm{C}\right)$;

$\operatorname{Pr} \quad$ pressure (hPA)

$\mathrm{RH} \quad$ relative humidity $(\%)$

Va $\quad$ air speed $(\mathrm{m} / \mathrm{s})$

WBGT Wet Bulb Globe Temperature;

PMV Predicted Mean Vote;

PPD Predicted Percentage of Dissatisfied (\%);

DR Dose Rate, dose per unit time (mg/day);

ADR Acute Dose Rate, dose from a single event or average over a limited time period (e.g., 1 day).

ADD Average Daily Dose, dose rate averaged over a pathway-specific period of exposure expressed as a daily dose on a per-unit-body-weight basis (mg/kg-day); 


\section{Appendix A}
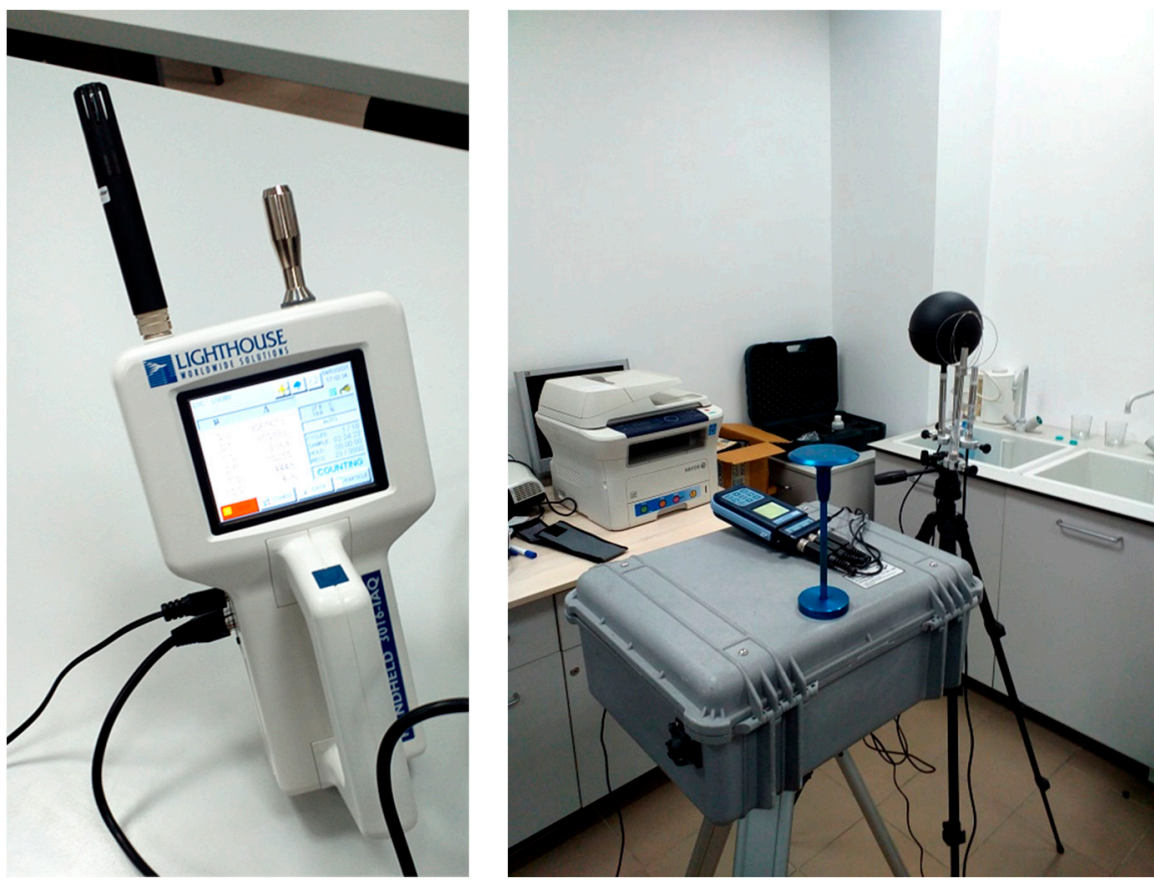

Figure A1. Instrumentation used in the current study (particle counter, PM monitor, and thermal microclimate equipment).

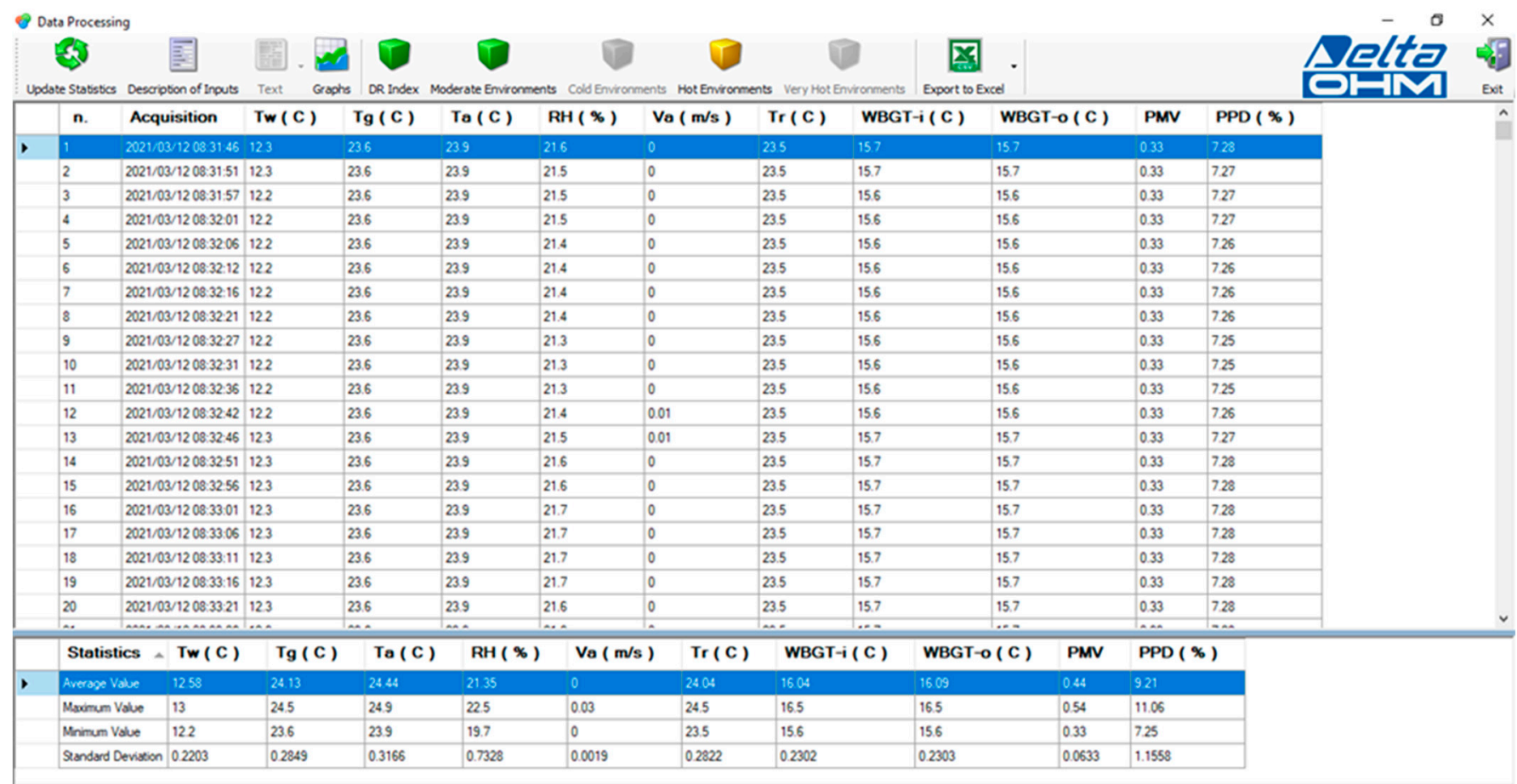

Figure A2. Screen capture of DeltaLog 10 software showing the data acquisition performed during the practical works of Group D. 


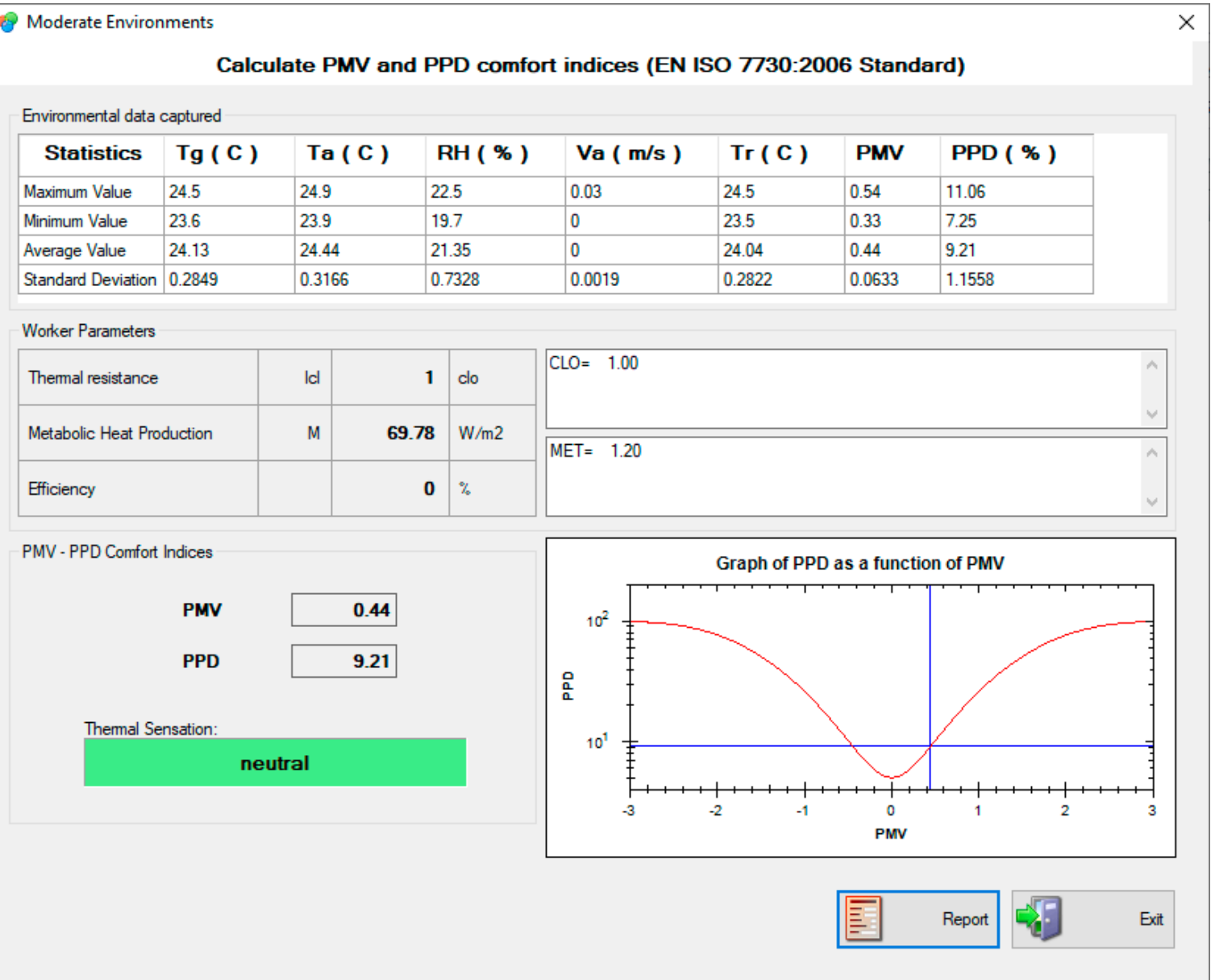

Figure A3. Screen capture of DeltaLog 10 software presenting the thermal sensation assessment based on PMV and PPD indices.

\begin{tabular}{|c|c|c|c|c|c|c|}
\hline \multirow[t]{2}{*}{ Date Created: $6 / 8 / 2021$} & \multicolumn{6}{|c|}{$\begin{array}{l}\text { Valahia Campus | Inhalation | ADD | Central Tendency | Air | School | Indoors at School | Male and Female | Sedentary/Passive | Short-Term (activity } \\
\text { specific) | Add to list using 'manage contaminants' }\end{array}$} \\
\hline & \multicolumn{3}{|c|}{20 years to $<21$ years } & \multicolumn{3}{|c|}{21 years to $<50$ years } \\
\hline Parameter & Value & Units & Description/Weight & Value & Units & Description/Weight \\
\hline \multicolumn{7}{|l|}{ ADR } \\
\hline ADD & 0.000386 & $\mathrm{mg} / \mathrm{kg}$-day & 3.33E-02 & \multicolumn{2}{|c|}{$0.000229 \mathrm{mg} / \mathrm{kg}$-day } & 9.67E-01 \\
\hline \multicolumn{7}{|l|}{ LADD } \\
\hline \multicolumn{7}{|l|}{ Adj. Air Conc (Lifetime) } \\
\hline \multicolumn{7}{|l|}{ Adj. Air Conc (Less than Lifetime) } \\
\hline \multirow{2}{*}{\multicolumn{7}{|c|}{$\begin{array}{l}\text { This row intentionally blank } \\
\text { This row intentionally blank }\end{array}$}} \\
\hline & & & & & & \\
\hline Concentration (C) & \multicolumn{2}{|c|}{$0.037 \mathrm{mg} / \mathrm{m} 3$} & & \multicolumn{2}{|c|}{$0.037 \mathrm{mg} / \mathrm{m} 3$} & \\
\hline Exposure Frequency (EF) & \multicolumn{2}{|c|}{140 days/year } & user-defined; Mean & \multicolumn{2}{|c|}{140 days/year } & user-defined; Mean \\
\hline Exposure Duration (ED) & \multicolumn{2}{|c|}{1 years } & Duration based on age bil & \multicolumn{2}{|c|}{29 years } & Duration based on age bin \\
\hline Averaging Time (AT) & \multicolumn{2}{|c|}{365 days } & ED * 365 days & \multicolumn{2}{|c|}{10585 days } & ED * 365 days \\
\hline Inhalation Rate (InhR) & \multicolumn{2}{|c|}{$0.0053 \mathrm{~m} 3 / \mathrm{min}$} & EFH Table 6-2 M\&F; Mean & \multicolumn{2}{|c|}{$0.00442069 \mathrm{~m} 3 / \mathrm{min}$} & EFH Table 6-2 M\&F; Mean; \\
\hline Exposure Time (ET) & \multicolumn{2}{|c|}{$367 \mathrm{~min} /$ day } & EFH Table 16-17 M\&F; Me & \multicolumn{2}{|c|}{$295.4 \mathrm{~min} /$ day } & EFH Table 16-18 M\&F; Mea \\
\hline Body Weight (BW) & \multirow{2}{*}{\multicolumn{2}{|c|}{$71.6 \mathrm{~kg}$}} & EFH Table 8-3 M\&F; Mean & \multicolumn{2}{|c|}{$81.02068966 \mathrm{~kg}$} & EFH Table 8-3 M\&F; Mean; \\
\hline Ingestion Rate (IR) | & & & & & & \\
\hline
\end{tabular}

Figure A4. Screen capture of ExpoFIRST Version 2.0 application for inhalation dose calculation (EPA's exposure factors interactive resource for scenarios tool https:/ / cfpub.epa.gov/ncea/risk/recordisplay.cfm?deid=322489\#tab-3, accessed on 5 June 2021). 


\section{References}

1. Chereminisoff, N.P. Handbook of Air Pollution Prevention and Control, 1st ed.; Butterworth-Heinemann: Oxford, UK, $2002 ;$ pp. 1-477.

2. Brown, J.S.; Gordon, T.; Price, O.; Asgharian, B. Thoracic and respirable particle definitions for human health risk assessment. Part Fibre Toxicol. 2013, 10, 12. [CrossRef] [PubMed]

3. Burnett, R.T.; Arden Pope, C.; Ezzati, M.; Olives, C.; Lim, S.S.; Mehta, S.; Shin, H.H.; Singh, G.; Hubbell, B.; Brauer, M.; et al. An integrated risk function for estimating the global burden of disease attributable to ambient fine particulate matter exposure. Environ. Health Perspect. 2014, 122, 397. [CrossRef] [PubMed]

4. Schnelle, K.B., Jr.; Brown, C.A. Air Pollution Control Technology Handbook, 1st ed.; CRC Press: Boca Raton, FL, USA, 2001; pp. 1-408.

5. Hvidtfeldt, U.A.; Geels, C.; Sørensen, M.; Ketzel, M.; Khan, J.; Tjønneland, A.; Christensen, J.H.; Brandt, J.; Raaschou-Nielsen, O. Long-term residential exposure to PM2.5 constituents and mortality in a Danish cohort. Environ. Int. 2019, 133, 105268. [CrossRef] [PubMed]

6. Héroux, M.-E.; Anderson, H.R.; Atkinson, R.; Brunekreef, B.; Cohen, A.; Forastiere, F.; Hurley, F.; Katsouyanni, K.; Krewski, D.; Krzyzanowski, M.; et al. Quantifying the health impacts of ambient air pollutants: Recommendations of a WHO/Europe Project. Int. J. Public Health 2015, 60, 619-627. [CrossRef] [PubMed]

7. Hamra, G.B.; Guha, N.; Cohen, A.; Laden, F.; Raaschou-Nielsen, O.; Samet, J.M.; Vineis, P.; Forastiere, F.; Saldiva, P.; Yorifuji, T.; et al. Outdoor particulate matter exposure and lung cancer: A systematic review and meta analysis. Environ. Health Perspect. 2014, 122, 906. [CrossRef] [PubMed]

8. Tarín-Carrasco, P.; Im, U.; Geels, C.; Palacios-Peña, L.; Jiménez-Guerrero, P. Contribution of fine particulate matter to present and future premature mortality over Europe: A non-linear response. Environ. Int. 2021, 153, 106517. [CrossRef] [PubMed]

9. Xu, T.; Hou, J.; Cheng, J.; Zhang, R.; Yin, W.; Huang, C.; Zhu, X.; Chen, W.; Yuan, J. Estimated individual inhaled dose of fine particles and indicators of lung function: A pilot study among Chinese young adults. Environ. Pollut. 2018, 235, 505-513. [CrossRef]

10. Cohen, A.J.; Brauer, M.; Burnett, R.; Anderson, H.R.; Frostad, J.; Estep, K.; Balakrishnan, K.; Brunekreef, B.; Dandona, L.; Dandona, R.; et al. Estimates and 25-year trends of the global burden of disease attributable to ambient air pollution: An analysis of data from the Global Burden of Diseases Study 2015. Lancet 2017, 389, 1907-1918. [CrossRef]

11. Leclercq, B.; Happillon, M.; Antherieu, S.; Hardy, E.M.; Alleman, L.Y.; Grova, N.; Perdrix, E.; Appenzeller, B.M.; Lo Guidice, J.-M.; Coddeville, P.; et al. Differential responses of healthy and chronic obstructive pulmonary diseased human bronchial epithelial cells repeatedly exposed to air pollution-derived PM4. Environ. Pollut. 2016, 218, 1074-1088. [CrossRef]

12. Abd Aziz, A.; Lee, K.; Park, B.; Park, H.; Park, K.; Choi, I.; Chang, I. Comparative study of the airborne microbial communities and their functional composition in fine particulate matter (PM2.5) under non-extreme and extreme PM2.5 conditions. Atmos. Environ. 2018, 194, 82-92. [CrossRef]

13. Hu, W.; Wang, Y.; Wang, T.; Ji, Q.; Jia, Q.; Meng, T.; Ma, S.; Zhang, Z.; Li, Y.; Chen, R.; et al. Ambient particulate matter compositions and increased oxidative stress: Exposure-response analysis among high-level exposed population. Environ. Int. 2021, 147, 106341. [CrossRef]

14. Liu, H.-Y.; Dunea, D.; Iordache, S.; Pohoata, A. A Review of Airborne Particulate Matter Effects on Young Children's Respiratory Symptoms and Diseases. Atmosphere 2018, 9, 150. [CrossRef]

15. WHO. Methods for Monitoring Indoor Air Quality in Schools. Available online: https://www.euro.who.int/__data/assets/pdf_ file/0011/147998/e95417.pdf (accessed on 2 April 2021).

16. Wang, B.; Tang, Z.; Li, Y.; Cai, N.; Hu, X. Experiments and simulations of human walking-induced particulate matter resuspension in indoor environments. J. Clean. Prod. 2021, 295, 126488. [CrossRef]

17. Karri, R.R.; Heibati, B.; Yusup, Y.; Rafatullah, M.; Mohammadyan, M.; Sahu, J.N. Modeling airborne indoor and outdoor particulate matter using genetic programming. Sustain. Cities Soc. 2018, 43, 395-405. [CrossRef]

18. Oprea, M.; Ianache, C.; Mihalache, S.F.; Dragomir, E.G.; Dunea, D.; Iordache, S.; Savu, T. On the development of an intelligent system for particulate matter air pollution monitoring, analysis and forecasting in urban regions. In Proceedings of the 19th International Conference on System Theory, Control and Computing (ICSTCC), Cheile Gradistei, Romania, 14-16 October 2015; pp. 711-716.

19. CEN EN 16450:2017. Ambient Air-Automated Measuring Systems for the Measurement of the Concentration of Particulate Matter (PM10; PM2.5). Available online: https:/ / standards.iteh.ai/catalog/standards/cen/21722c9a-74b9-4f47-901c-40ecec9 5dcfe/en-16450-2017 (accessed on 2 April 2021).

20. Oprea, M.; Dunea, D.; Liu, H.-Y. Development of a Knowledge Based System for analyzing particulate matter air pollution effects on human health. Environ. Eng. Manag. J. 2017, 16, 669-676. [CrossRef]

21. Feenstra, B.; Papapostolou, V.; Hasheminassab, S.; Zhang, H.; Der Boghossian, B.; Cocker, D.; Polidori, A. Performance evaluation of twelve low-cost PM2.5 sensors at an ambient air monitoring site. Atmos. Environ. 2019, 216, 116946. [CrossRef]

22. Dunea, D.; Iordache, S..; Ianache, C. Relationship between airborne particulate matter and weather conditions in Targoviste urban area during cold months. Rev. Roum. Chim 2015, 60, 595-601.

23. Dunea, D.; Liu, H.-Y.; Iordache, S.; Buruleanu, L.; Pohoata, A. Liaison between exposure to sub-micrometric particulate matter and allergic response in children from a petrochemical industry city. Sci. Total Environ. 2020, 745, 141170. [CrossRef]

24. Schibuola, L.; Tambani, C. Indoor environmental quality classification of school environments by monitoring PM and CO2 concentration levels. Atmos. Pollut. Res. 2019, 11, 332-342. [CrossRef] 
25. TSI. Available online: https://tsi.com/products/aerosol-and-dust-monitors/dust-monitors/dusttrak-drx-aerosol-monitor-8533/ (accessed on 2 April 2021).

26. Lighthouse. Available online: https://www.golighthouse.com/en/airborne-particle-counters/handheld-3016-iaq (accessed on 2 April 2021).

27. DeltaOhm. Available online: https://www.deltaohm.com/product/hd32-3-wbgt-pmw-ppd-measurement-2/ (accessed on 2 April 2021).

28. Chokroverty, S. Sleep and breathing in neuromuscular disorders, Chapter 64. In Handbook of Clinical Neurology; Montagna, P., Chokroverty, S., Eds.; Elsevier: Amsterdam, The Netherlands, 2011; Volume 99, pp. 1087-1108. [CrossRef]

29. Taylor, W.L.; Schuldt, S.J.; Delorit, J.D.; Chini, C.M.; Postolache, T.T.; Lowry, C.A.; Brenner, L.A.; Hoisington, A.J. A framework for estimating the United States depression burden attributable to indoor fine particulate matter exposure. Sci. Total Environ. 2021, 756, 143858. [CrossRef]

30. Fisk, W.J.; Chan, W.R. Effectiveness and cost of reducing particle-related mortality with particle filtration. Indoor Air 2017, 27, 909-920. [CrossRef] [PubMed]

31. Hussein, T.; Löndahl, J.; Thuresson, S.; Alsved, M.; Al-Hunaiti, A.; Saksela, K.; Aqel, H.; Junninen, H.; Mahura, A.; Kulmala, M. Indoor Model Simulation for COVID-19 Transport and Exposure. Int. J. Environ. Res. Public Health 2021, 18, 2927. [CrossRef] [PubMed]

32. Wild, C.P. Complementing the genome with an "exposome": The outstanding challenge of environmental exposure measurement in molecular epidemiology. Cancer Epidemiol. Biomark. Prev. 2005, 14, 1847-1850. [CrossRef] [PubMed]

33. Petter, L.; Fagerland, M.W. Chapter 11-Statistical Inference. In Research in Medical and Biological Sciences, 2nd ed.; Laake, P., Benestad, H.B., Olsen, B.R., Eds.; Academic Press: New York, NY, USA, 2015; pp. 379-430. [CrossRef]

34. Vervoort, R.; Blocken, B.; van Hooff, T. Reduction of particulate matter concentrations by local removal in a building courtyard: Case study for the Delhi American Embassy School. Sci. Total Environ. 2019, 686, 657-680. [CrossRef]

35. Raysoni, A.U.; Sarnat, J.A.; Sarnat, S.E.; Garcia, J.H.; Holguin, F.; Luèvano, S.F.; Li, W.-W. Binational school-based monitoring of traffic-related air pollutants in El Paso, Texas (USA) and Ciudad Juárez, Chihuahua (México). Environ. Pollut. 2011, 159, 2476-2486. [CrossRef]

36. Dunea, D.; Iordache, S.; Bohler, T.; Huber, F.; Leitner, P. Evaluating the Air Pollution Impact Using Environmental Monitoring, Dispersion Modeling and Volunteered Geographic Information Systems. Rev. Chim. 2017, 68, 835-840. [CrossRef]

37. Martins, V.; Faria, T.; Diapouli, E.; Manousakas, M.I.; Eleftheriadis, K.; Viana, M.; Almeida, S.M. Relationship between indoor and outdoor size-fractionated particulate matter in urban microenvironments: Levels, chemical composition and sources. Environ. Res. 2020, 183, 109203. [CrossRef]

38. Mosqueron, L.; Momas, I.; Le Moullec, Y. Personal exposure of Paris office workers to nitrogen dioxide and fine particles. Occup. Environ. Med. 2002, 59, 550-555. [CrossRef]

39. Blondeau, P.; Iordache, V.; Poupard, O.; Genin, D.; Allard, F. Relationship between outdoor and indoor air quality in eight French schools. Indoor Air 2005. [CrossRef]

40. Stabile, L.; Dell'isola, M.; Russi, A.; Massimo, A.; Buonanno, G. The effect of natural ventilation strategy on indoor air quality in schools. Sci. Total Environ. 2017, 595, 894-902. [CrossRef]

41. Rengasamy, S.; Eimer, B.; Shaffer, R.E. Simple respiratory protection-Evaluation of the filtration performance of cloth masks and common fabric materials against 20-1000 nm size particles. Ann. Occup. Hyg. 2010, 54, 789-798.

42. Matuschek, C.; Moll, F.; Fangerau, H.; Fischer, J.C.; Zänker, K.; Van Griensven, M.; Schneider, M.; Kindgen-Milles, D.; Knoefel, W.T.; Lichtenberg, A.; et al. Face masks: Benefits and risks during the COVID-19 crisis. Eur. J. Med. Res. 2020, 25, 32. [CrossRef]

43. Oprea, M.; Dunea, D. SBC-MEDIU: A multi-expert system for environmental diagnosis. Environ. Eng. Manag. J. 2010, 9, 205-213. [CrossRef]

44. Zuurbier, M.; Hoek, G.; Hazel, P.V.D.; Brunekreef, B. Minute ventilation of cyclists, car and bus passengers: And experimental study. Environ. Health 2009, 8, 48-58. [CrossRef]

45. Cherrie, J.W.; Apsley, A.; Cowie, H.; Steinle, S.; Mueller, W.; Lin, C.; Horwell, C.J.; Sleeuwenhoek, A.; Loh, M. Effectiveness of face masks used to protect Beijing residents against particulate air pollution. Occup. Environ. Med. 2018, 75, 446-452. [CrossRef]

46. Johra, H.; Heiselberg, P. Influence of internal thermal mass on the indoor thermal dynamics and integration of phase change materials in furniture for building energy storage: A review. Renew. Sustain. Energy Rev. 2017, 69, 19-32. [CrossRef]

47. Johra, H.; Heiselberg, P.; Le Dréau, J. Influence of envelope, structural thermal mass and indoor content on the building heating energy flexibility. Energy Build. 2019, 183, 325-339. [CrossRef]

48. Švajlenka, J.; Kozlovská, M.; Pošiváková, T. Assessment and biomonitoring indoor environment of buildings. Int. J. Environ. Health Res. 2017, 5, 427-439. [CrossRef]

49. Švajlenka, J.; Kozlovská, M.; Pošiváková, T. Biomonitoring the indoor environment of agricultural buildings. Ann. Agric. Environ. Med. 2018, 25, 292-295. [CrossRef]

50. Dessimond, B.; Annesi-Maesano, I.; Pepin, J.-L.; Srairi, S.; Pau, G. Academically Produced Air Pollution Sensors for Personal Exposure Assessment: The Canarin Project. Sensors 2021, 21, 1876. [CrossRef]

51. Kaliszewski, M.; Włodarski, M.; Młyńczak, J.; Kopczyński, K. Comparison of Low-Cost Particulate Matter Sensors for Indoor Air Monitoring during COVID-19 Lockdown. Sensors 2020, 20, 7290. [CrossRef] 
52. Savu, T.; Jugravu, B.A.; Dunea, D. On the Development of a PM2.5 Monitoring Network for Real-time Measurements in Urban Environments. Rev. Chim. 2017, 68, 796-801. [CrossRef]

53. Borghi, F.; Fanti, G.; Cattaneo, A.; Campagnolo, D.; Rovelli, S.; Keller, M.; Spinazzè, A.; Cavallo, D.M. Estimation of the Inhaled Dose of Airborne Pollutants during Commuting: Case Study and Application for the General Population. Int. J. Environ. Res. Public Health 2020, 17, 6066. [CrossRef]

54. Daiber, A.; Kuntic, M.; Hahad, O.; Delogu, L.G.; Rohrbach, S.; Di Lisa, F.; Schulz, R.; Münzel, T. Effects of air pollution particles (ultrafine and fine particulate matter) on mitochondrial function and oxidative stress-Implications for cardiovascular and neurodegenerative diseases. Arch. Biochem. Biophys. 2020, 696, 108662. [CrossRef]

55. Travaglio, M.; Yu, Y.; Popovic, R.; Selley, L.; Leal, N.S.; Martins, L.M. Links between air pollution and COVID-19 in England. Environ. Pollut. 2021, 268 Pt A, 115859. [CrossRef]

56. Yao, Y.; Chen, X.; Chen, W.; Wang, Q.; Fan, Y.; Han, Y.; Wang, T.; Wang, J.; Qiu, X.; Zheng, M.; et al. Susceptibility of individuals with chronic obstructive pulmonary disease to respiratory inflammation associated with short-term exposure to ambient air pollution: A panel study in Beijing. Sci. Total Environ. 2021, 766, 142639. [CrossRef]

57. Cincinelli, A.; Martellini, T. Indoor Air Quality and Health. Int. J. Environ. Res. Public Health 2017, 14, 1286. [CrossRef]

58. Mullen, C.; Grineski, S.E.; Collins, T.W.; Mendoza, D.L. Effects of PM2.5 on Third Grade Students' Proficiency in Math and English Language Arts. Int. J. Environ. Res. Public Health 2020, 17, 6931. [CrossRef]

59. Kim, J.-H.; Yeo, M.-S. Effect of Flow Rate and Filter Efficiency on Indoor PM2.5 in Ventilation and Filtration Control. Atmosphere 2020, 11, 1061. [CrossRef] 